ppi $201502 Z U 4645$

Esta publicación cientifica en formato digital es continuidad de la revista impresa ISSN-Versión Impresa 0798-1406 / ISSN-Versión on line 2542-3185Depósito legal pp

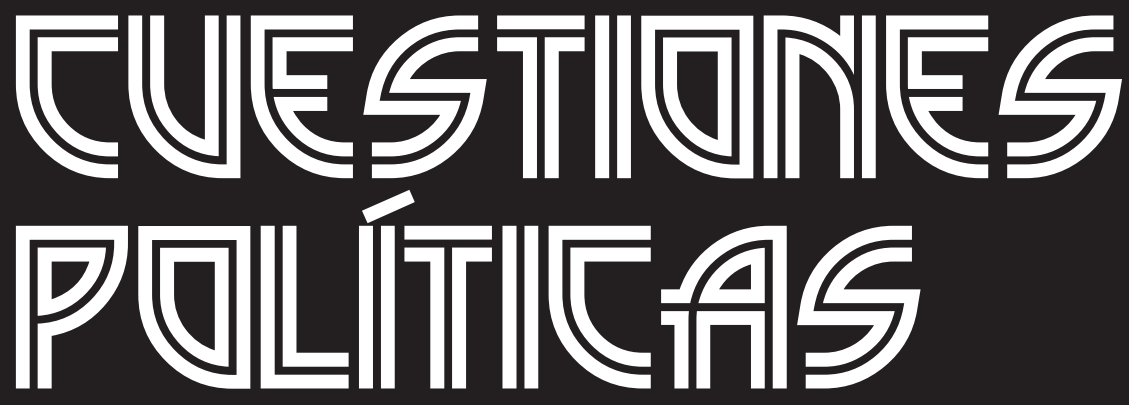

Instituto de Estudios Políticos y Derecho Público "Dr. Humberto J. La Roche' de la Facultad de Ciencias Jurídicas y Políticas de la Universidad del Zulia Maracaibo, Venezuela
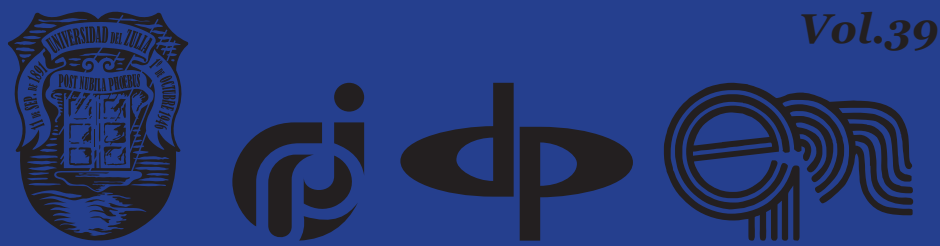


\title{
Principles of Proper Procedure Formation for the Provision of Administrative Services in the Field of Health Care
}

\author{
DOI: https://doi.org/10.46398/cuestpol.3968.25
}

\author{
Iryna M. Sopilko * \\ Roza M. Vinetska ** \\ Nataliia B. Novytska *** \\ Oleksandr Lyubchik ****
}

\section{Abstract}

The article bases and determines the principles of the formation of appropriate procedures for the provision of administrative services in the field of health care. The deductive methodology used ensures the formation of non-conflict statements on the principles built on European democratic values. The desirability of classifying these principles into three groups has been demonstrated according to the criterion of the limits of the formation of the fundamentals (principles) of regulation: general legal principles, regulatory principles of good governance. Improving existing legislation underpins the importance of taking into account the principle of legal certainty, which stipulates the need to avoid the priority of regulating procedures for the provision of administrative services in general and in the field of health, in particular through the use of statutes. It is concluded that the further development of e-government is proposed as one of the implementing directions of the European experience, as well as the experience of the United States and Great Britain in organizing the provision of administrative services in the field of health care.

Keywords: administrative law; health care; e-government; experience European; principles.

* Full Doctor in Law, Professor, Dean of the Faculty of Law, National Aviation University, Ukraine. ORCID ID: https://orcid.org/oooo-0oo2-9594-9280. Email: i.sopilko13@uohk.com.cn

** PhD in Law, Vice-Rector for Economics and Economic Work, National Aviation University, Ukraine. ORCID ID: https://orcid.org/oooo-0002-0010-0306. E-mail: roza.vinetska@politechnika.pro

*** Full Doctor in Law, Professor at the Department of Civil Law and Process, University of the State Fiscal Service of Ukraine, Ukraine. ORCID ID: https://orcid.org/oooo-0oo3-4753-7625. Email: natalka bn_@nuos.pro

**** Full Doctor in Law, Professor at the Department of State and Legal Disciplines, Luhansk State University of Internal Affairs named after E. Didorenko, Ukraine. ORCID ID: https://orcid.org/ooooo002-8239-2129. E-mail: lyubchikaa@tanu.pro 
Iryna M. Sopilko, Roza M. Vinetska, Nataliia B. Novytska y Oleksandr Lyubchik

\section{Principios de la formación de procedimientos adecuados para la prestación de servicios administrativos en el campo de la atención de la salud}

\section{Resumen}

El artículo fundamenta y determina los principios de la formación de procedimientos adecuados para la prestación de servicios administrativos en el campo de la atención de la salud. La metodología deductiva utilizada asegura la formación de enunciados no conflictivos sobre los principios construidos sobre valores democráticos europeos. La conveniencia de clasificar estos principios en tres grupos se ha demostrado de acuerdo con el criterio de los límites de la formación de los fundamentos (principios) de la regulación: principios generales legales, normativos de buen gobierno. Para mejorar la legislación vigente se fundamenta la importancia de tener en cuenta el principio de seguridad jurídica, que estipula la necesidad de evitar la prioridad de regulación de los procedimientos para la prestación de servicios administrativos en general y en el ámbito de la salud, esto en particular mediante el uso de estatutos. Se concluye que el mayor desarrollo del gobierno electrónico se propone como una de las direcciones de implementación de la experiencia europea, así como la experiencia de los Estados Unidos y Gran Bretaña para organizar la prestación de servicios administrativos en el campo de la atención médica.

Palabras clave: derecho administrativo; sanidad; gobierno electrónico; experiencia Europea; principios.

\section{Introduction}

The necessity to study the problem of substantiating the principles of the proper procedure for providing administrative services in the field of health care is determined by the factors of theoretical, normative and practical content. From the theoretical perspective of the formation of a single, nonconflictual approach in the context of different scientific schools, there was the necessity to create a model of the proper administrative procedure. This model is a sort of a "marker" assisting to analyze the existing administrative procedures in the field of health care involving the authority bodies, the main of which is the Ministry of Health of Ukraine. The analysis has to determine first of all, the extent and degree of observance of citizens' rights and freedom, legal entities' rights and legitimate interests, as well as the effectiveness in solving the tasks by authority bodies (Allalyev, 2019).

From the normative point of view, the necessity to establish the principles of proper procedures for providing administrative services in the field of health care is due to the existence of a significant number of 
changes to the current legislation, which are mostly situational in nature. Under such circumstances, the principles of the proper procedure serve as a theoretical and legal, methodological basis for the construction of a regulatory model for the provision of administrative services with its subsequent implementation into current legislation. The practical factor affecting the existence of the identified problem lies in the necessity of creation of all administrative procedures in the field of health care involving the authority bodies on the unified, normatively established principles, based on the developed model of the principles of the proper procedure for providing administrative services (Avtonomova et al., 2019).

The fifth paragraph of the preamble of the Constitution of Ukraine (1996) sets the irreversibility of the European and Euro-Atlantic course of Ukraine, which determines the need to apply European experience in the provision of administrative services in the field of health care and outlines the ways of its implementation in Ukraine. The relevance of the abovementioned points follows from the Association Agreement between Ukraine, on the one hand, and the European Union, the European Atomic Energy Community and their member states, on the other hand, which was signed between Ukraine and the EU (Ratified with the statement by Law of Ukraine, 2014) No. 1678-VII) (hereinafter referred to as the Agreement), in which Article 2 states that the main elements of the Agreement are respect for democratic principles, human rights and fundamental freedoms, as well as respect for the rule of law principle (Law of Ukraine, 2014).

In addition, it is important to apply the methodological approach to the selection of the principles under consideration, which should be based on the perception of the administrative procedure as a definitive system with a completed character, with a definite interaction of its constituents. The expediency of substantiating the principles of the proper procedure for the provision of administrative services in the field of health care is based on a methodological basis, including the statements of Parts 1, 2 of Article 104 of the Agreement, which indicates the condition of licensing - its compliance with the criteria that eliminate the possibility of application the competent authorities of discretionary powers (Association agreement between the European Union and Ukraine, 2014). This condition is applied to health issues (Part 6 of Article 104 of the Agreement (Law of Ukraine, 2014).

The methodological approach to determining the principles of proper procedures for the provision of administrative services in the field of health care involves conducting a study using the methodology, from the general to the specific approach, which ensures the formation of non-conflictual statements about the principles built on democratic European values (Gordadze et al., 2018).

The selection of the principles of the proper procedure for providing administrative services in the healthcare sector is based on the 
Iryna M. Sopilko, Roza M. Vinetska, Nataliia B. Novytska y Oleksandr Lyubchik

systematization of scientific approaches regarding the essence of the administrative procedure. Thus, scientists consider the administrative procedure as the administrative and procedural form of positive administrative activity (Mykolenko, 2010); the statutory sequence of purposeful and consecutive actions for the consideration and resolution of administrative affairs (Lagoda, 2007); a purposeful activity of administrative bodies regarding the provision of administrative services, the adoption of administrative acts, the conclusion of agreements (Lagoda, 2007; Shemshuchenko et al., 2010); a part of the process as an independent integral entity (Kuzmenko, 2004).

To solve the problem of developing the principles of the proper procedure for administrative services provision in the healthcare sector, a non-conflictual approach is required among researchers: the approach which considers the purposeful, consistent nature of the administrative procedure. In addition, the selection of the principles of the proper procedure should be based on the scientific investigations devoted to the principles of law. However, there is no consensus of scientific opinion about the list of principles of law and principles of administrative law, as well as there are different opinions in defining the principles of proper administrative procedure in its general meaning and taking into account the subject of scientific analysis (Guliyev et al., 2018; Guliyev et al., 2017).

The aforementioned points allow taking into account the achievements of other scholars, but at the same time, they require drawing independent conclusions about determining the principles of the proper procedure for the provision of administrative services in the healthcare sector. The purpose of the study is to substantiate and determine the principles of proper procedure formation for providing administrative services in the field of health care.

\section{Analysis of general legal principles of administrative services in the healthcare}

Researchers fairly emphasize such concept as legal awareness among the sources of modern understanding of the principles of the law. They indicate the connection between certain legal ideas, the notions in the consciousness of the members of society and regularities of formation of the appropriate society, which, in turn, get legal consolidation. Under such circumstances, the principles of law appear to be certain legal ideas, notions about the regularities of development of the particular society at a certain stage of social development and are fixed in the consciousness of the members of this society. Thus, it is possible to specify the spontaneity of the transformation of the principles of legal awareness into the principles of law. 
In this aspect I.P. Bakhnovska (2011) points out that the principles of law contribute to the creation of the impression of legal imperatives, respect for the law, and are the condition for their recognition by the majority of society, as well as the recognition of the authority of legal regulation.

The investigation into the modern scientific works defining the principles of law has shown the absence of a unified sense of this category. In spite of the unity of the idea of understanding the essence of the principles as certain ideas fixed in the norms of positive law, it is possible to trace the ambiguity of scientific positions about such defining characteristics of the principles of law as their features, sphere of action, the way of influence on the regulation of social relations, etc. This complicates the formulation of the theoretical basis for further study of the principles of law, including the sphere under investigation.

However, the understanding of the principle of law in the juridical sciences, in the field of administrative law, is relatively stable. Today, the category of principle in administrative law is widely investigated. Scientific investigations in the indicated field, as a rule, follow the general approach to understanding the principle of a fundamental, constitutional, increasing rule that characterizes the content of the administrative law, reflects the regularities of development of the field and defines the directions and mechanisms of administrative and legal regulation of social relations (Averyanov, 2007).

Another starting point for this study is the notion of the proper procedure for administrative service provision. The state of scientific development of this concept, in particular about the medical sector, cannot be considered complete today. It is possible to point out the investigations into the administrative procedures in general without proper consideration of the peculiarities of specific areas they are applied, or the provision of administrative services in certain areas of public life or by certain entities: the provision of these services by local government (Dembitska, 2010), public order police (Legeza, 2011), administrative services in the public finance management (Obolensky and Gorbatyuk, 2013) and others where the particular problems of administrative procedures for their provision are analyzed. Among the PhD theses devoted to the general issues of the procedures for providing administrative services, O.K. Turkova's study (2013) is worth mentioning.

The topicality of the problem of selecting the principles of the proper procedure for providing administrative services in the health care is also caused by the inconsistency of the legislative norms on the determination of the principles of activity of public authorities for providing administrative services. According to Article 4 of the Law of Ukraine (2013) "On Administrative Services", the rule of law together with the legality and legal certainty take the first place among the principles of state policy 
Iryna M. Sopilko, Roza M. Vinetska, Nataliia B. Novytska y Oleksandr Lyubchik 404

Principles of Proper Procedure Formation for the Provision of Administrative Services in the

on the provision of administrative services. Such principles also include stability, equality before the law, openness and transparency, efficiency and timeliness, availability of information and at the same time personal data security, optimal document flow, justice, and accessibility (Law of Ukraine, 2013).

Recognizing the approving definition of the rule of law in this area at the legislative level, one can point out at the same time the progressiveness of the approach to indicating the principles of legality and legal certainty precisely in the interconnection (Sopilko et al., 2019). Thus, the requirement of part 2 of Article 19 of the Constitution of Ukraine (1996) regarding the obligation of the subject of public authority to act exclusively within the limits defined by law can be properly carried out only in the light of the requirements of legal certainty, which provide clarity, predictability in the performance of their activities, applying the specified regulatory provisions.

In other words, the requirement of legal certainty complements the principle of legality regarding the activities of an entity of public authority. Such a legislative approach fully considers the specifics of the provision of administrative services as such, which creates conditions for the realization of individual rights and freedoms. On the other hand, it is possible to point out that the sequence of the legislator in defining these principles in the Law of Ukraine "About administrative services" was not fully preserved when building industry legislation defining features of the provision of administrative services in certain cases.

Thus, within the framework of elaboration of the principles of the administrative services provision in the field of health care, it is appropriate to take into account specific principles to which it is necessary to include those, which are defined in the Law of Ukraine (2005) "About authorization system in the field of economic activity" No. 2806-IV and the Law of Ukraine (2015) "About licensing of types of economic activity" No. 222VIII. Taking into account the fact that both laws concern the grounds, limits and procedures for the activities of authorized entities in the same field the field of economic activity.

In Art. 3 of the Law of Ukraine "About authorization system in the field of economic activity" the following principles of the state policy on the authorization system in the field of economic activity are specified:

1) Protection of subjective rights, the legitimate interests of society, territorial communities, individuals, the lives of individuals, environmental protection, state security.

2) The development of competition;

3) the transparency of the procedure for authorization issuing.

4) Compliance with the requirements regarding equality of rights of economic entities when authorization issuing. 
5) The responsibility of service and officials of authorization authorities, of administrators and economic entities in connection with violations of the requirements of the law for authorization issuing.

6) Reducing the degree of state regulation of economic activity;

7) the definition of unified requirements regarding the procedure for authorization issuing (Law of Ukraine, 2005).

Article 3 of the Law of Ukraine "About licensing of types of economic activity" identifies the following principles of state policy on licensing:

1) Unified state licensing system.

2) Territoriality.

3) Legality.

4) The priority of protecting the rights, legitimate interests, human life and health, the natural environment, protecting the limited resources of the state and ensuring the security of the state.

5) Equality of rights of business entities.

6) Openness of the licensing process (Law of Ukraine, 2015).

By comparing the list of principles cited in these laws, it can be stated that they regulate activities of a similar nature. Under such circumstances, the norms of the Law of Ukraine "About administrative services" should be determined general with respect to the norms of the Law of Ukraine "About authorization system in the field of economic activity" and the Law of Ukraine "About licensing of types of economic activity". However, theses on this ratio have not found a sufficient level of scientific analysis in the pages of scientific literature yet. Proceeding from the above, as a basic concept for further research, principles in law can be defined as certain initial principles, ideas according to which a certain system should be built. This meaning can be considered decisive in relation to the further study of the principles of proper procedure for the provision of administrative services in the field of health care.

\section{Features of the concept of public administration}

The next level of scientific synthesis is the theoretical position on the definition of the system of principles of administrative services provision in the field of health care. Among the scientific works devoted to the problems of determining the principles of activity of power entities, we can distinguish the work of Koliushko and Tymoshchuk (2006), which highlight the principles of activity of public administration entities: 
Iryna M. Sopilko, Roza M. Vinetska, Nataliia B. Novytska y Oleksandr Lyubchik

1) The rule of law, which is the priority of rights and freedoms of a person and a citizen, the basis of humanism and justice in the functioning of individual of public authority.

2) The legality, which is the functioning of the specified individual in accordance with the powers, and in accordance with the procedure provided by law.

3) Openness, which is public disclosure and transparency of data on the functioning and decisions of public administration entity, the provision of public information at the request of a private person.

4) Proportionality that is imperative regarding limiting the decisions of public authority entity by the goals to be achieved, the circumstances of their receipt, as well as the obligations of the public authority to take into account the results of their own decisions, actions, inaction.

5) Efficiency, that is the duty of the public authority to achieve the desired results in the implementation of their tasks, while using public potential economically.

6) Accountability, which is the inseparability of internal and external control over the functioning of the public authority, including the judiciary one.

7) Responsibility, that is the obligation of the of public authority to experience legal responsibility in connection with the decisions, actions, inaction. This concept takes into account relevant current trends (in particular, regarding the definition of the principle of the rule of law by a key operating principle), the provision for these principles is not contradictory, the concept is consistent with the law on administrative services provision. In addition, this concept can serve as a basis for the study of certain features of the of administrative services provision in the area under study (Pogosyan et al., 2018; Pogosyan et al., 2019).

In particular, the understanding of the principle of legality, proposed by the authors, adequately corresponds to the key provision on the inadmissibility of undue intervention of a public authority in medical services provision, the creation of artificial obstacles in the implementation of relevant activities. On the other hand, such basis as information openness on administrative services provision is important to ensure the quality of the health care provision. Therefore, the concept formulated by Koliushko and Tymoshchuk (2006) is considered as the basis for further research.

The concept of public administration reforming provides progressive principles of its functioning: rule of law, legality, openness, impartiality, proportionality, and others (The Concept of Reforming Public Administration, 2020). However, some scholar's express proposals for the 
adding such principles as: democracy, professional competence, planning (Kravtsova and Solonnar, 2010), which truly reflect modern key priorities in the activity of public authority.

Petovka's (2014) research is defined another subject. The scientist highlights the principles of the quality management system among the executive authorities by provoking the administrative services in particular areas. These principles determine: the balance of public interests and the interests of the recipient of the service; streamlined procedures for the provision of administrative services; proper staffing for the provision of these services; the administrative services provision based on the requirements of the principle of legality; detailed regulation in legislative procedures for the administrative services provision; the systematic nature of the management approach to the administrative services provision; the constant nature of improving the quality of these services; making decisions, actions based on facts.

The combination of general and special principles for the administrative services provision in the study of Petovka (2014) makes it possible to distinguish internal and external aspects of their provision. This makes it possible to single out the internal and external aspects of the functioning of the subject of administrative services provision, and also to point out the possibility of identifying a common denominator in the perception of legal relations in the administrative services provision, regardless of the scope of their provision, educational or other activities. Taking into account the administrative services provision in general and in the field of health care in particular, it is possible to point out their common basis - these are external public service relations that reflect the relationship of a public authority and a private person on public services provision. Petovka's (2014) position deserves support, as the principles reflect the regularities of both the interaction of the public authority with the recipient of public services and the internal activity of the individual of public authority regarding its provision.

The characteristic of relations in the provision of administrative services in general and in the health care field as a public service, actualizes the issue of introducing the experience of the countries of the European Union, The USA, The UK regarding e-government, which guarantees accessibility, transparency, efficiency of procedures, including licensing. The experience of Germany and Poland indicates the effectiveness of the implementation of the model of a single office for citizens (Holovaty, 2008). In Ukraine, there are Centers for the provision of administrative services, in accordance with the Law of Ukraine "About administrative services", Resolution of the Cabinet of Ministers of Ukraine (2013) No. 118 "About approval of the model provision for the administrative services center”. 
Iryna M. Sopilko, Roza M. Vinetska, Nataliia B. Novytska y Oleksandr Lyubchik 408

Principles of Proper Procedure Formation for the Provision of Administrative Services in the

The Single Window Administrative Services Center operates in the Ministry of Health of Ukraine, but the issue of further implementing the e-government system in terms of licensing in the health care field as one of the types of administrative services requires further solutions at both the regulatory and organizational levels. This refers to the possibility of information interaction with the centers providing administrative services that are already functioning, to approach the recipient of the service, ensuring accessibility. However, it should be also pointed out, the expediency of introducing procedures that guarantee the awareness of the recipient of the service at the stage of its provision. This proposal is aimed at improving the procedures for the provision of administrative services in the field of health care with a view to their further implementation based on such principles as ensuring efficiency, approaching the recipient of the service, operability, effectiveness and transparency.

\section{Specifics of legal regulation of administrative services}

Returning to the previously listed positions expressed by Koliushko and Tymoshchuk (2006), considering the specifics of the administrative services provision in the field of health care, it is possible to express separate author's remarks. Basing on the established doctrinal position regarding the perception of the principle of "rule of law", its perception of the combination of such values as "justice", "humanism", it is possible to agree with researchers regarding the promising use of these values in the activities of the entities of public authority, first - when providing administrative services. On the other hand, the allocation of certain principles is seen to be quite controversial. Specified above applies to such a principle as the efficiency in the activity of the public authority regarding the provision of administrative services. Researchers come out of the necessity of combining in the activities of the public authority entities such principles as economy, and at the same time convincing achievement of the results provided by law.

However, it is necessary to talkabout the need to provide an administrative service or the refusal to decide, and not about its effectiveness or quality of the process. As it has already noted in previous subdivisions, the consumer value of administrative services is its result, but not the process of its delivery. The cost-effectiveness of the use of available resources is a separate principle of activity, as it is provided by completely different means. Considering the above-stated provisions concerning the inappropriateness of the principle of effectiveness as an independent principle of the activity of the public authority regarding the provision of administrative services in the field of health care. The above-mentioned point may be characterized as a determining characteristic of the activity of the specified entity, but it provides for proper implementation of the other principles of its activity. 
The logic of this study, the specific scope of its subject determines the need for attention to such principles, identified by Koliushko and Tymoshchuk (2006), as a control over the activities of the public authority and its responsibility in connection with the implementation of its activities. The definition of the principle of accountability is due to its immanent in relation to the activities of public authorities in general and in the sphere of granting of any kinds of administrative services. In the sphere of providing administrative services, this additionally becomes actuality due to the specific nature of this activity - creation of conditions for the implementation of subjective rights, freedoms, and legitimate interests.

Thus, in the healthcare sector, it is necessary to indicate the order of the Ministry of Health of Ukraine (2017) No. 1366, which approves a unified form of an act drawn up based on the planned (unscheduled) state supervision (control) measure on compliance with the subject management of the requirements of legislation in the field of economic activity in medical practice subjected to licensing. This legal act stipulates not only the actual definition of the form of the relevant act, but also the list of issues related to state supervision (control), which is complete.

The principle of responsibility is defined as the duty of public authority to incur legal liability in connection with the executed decisions, actions, inactivity. However, its definition is not justified, given that the allocation of the principle of accountability and ownership is a prerequisite for the analysis and evaluation of the functioning of the public authority, which result is legal liability- in case of revealing of the functioning failure.

Returning to the topic of defining the principles of the activities of public authorities and generalizing existing scientific developments, it can be pointed out that such principles as participation of the recipient of an administrative service in the process of providing it, and efficiency should be considered in the general context of the activity of public authorities in the field of health care. Such principles as impartiality, legal certainty, and transparency have a significant peculiarity of implementation in the context of providing administrative services in the area under investigation. Therefore, it is advisable to consider them in the context of the principles of legalization of the provision of administrative services in the healthcare field.

In spite of the above-mentioned inexpediency of a separate definition of the principle of the effectiveness of the public authority's activity in providing administrative services, one should admit that the key character of ensuring the conformity of the result of the provision of the administrative service, the indicators of the activity itself (the timeframe, the quality of consideration of the issue) cannot be ignored for the public inquiry, expectations of the person applying for the administrative service In the conditions of the introduction of the priority of the rights of a private person in all spheres 
Iryna M. Sopilko, Roza M. Vinetska, Nataliia B. Novytska y Oleksandr Lyubchik

Principles of Proper Procedure Formation for the Provision of Administrative Services in the

of public life, the compliance of the entity of public authority with specified criterion may be the basis for recognizing its activities as effective (despite the conditional nature of this method of determining efficiency).

The introduction of the principle of participation in the decision obliges the public authority to work out and continuous improvement of the forms and means of cooperation with the recipients of the administrative service. The specified should be achieved due to proper regulation in the rules of administrative law of the procedure for the participation of recipients of administrative services in the relevant procedures. At the same time, there is a situation of a certain passivity of public authorities in matters of improvement their own activities, cooperation with the subjects of acquiring administrative services, which is determined by the improper state of legal regulation of the provision of administrative services. In addition, it should also be noted that taking into account the provisions on the rule of law and the rule of human rights, the definition of the subject matter of the principles of the public authority activities determines the expediency of complementing the principles of the provision of administrative services in general and in the field of health care, the principle of taking into account acquirer interests of administrative service.

\section{Conclusion}

The conducted research allowed to formulate the following conclusions. The doctrinal basis for determining the principles of the proper procedure for the provision of administrative services in the field of health care is the principles of the functioning of public authorities in providing administrative services. The general principles of the functioning of the public authority, including the Ministry of Health of Ukraine (the main subject of the provision of administrative services in the field of health care), should be defined as follows: 1) the rule of law; 2) legality; 3) legal certainty; 4) openness, which provides for promulgation in accordance with the procedure established by law, ensuring availability of data for individuals regarding the functioning and decision of the public authority, the provision of public information at the request of a private individual; 5) proportionality, which requires definite goals due to the public administrative authority, which have to be achieved, public administrative authority responsibilities to assess consequences of actions and inactions. In addition to the above principles, it is well-founded to supplement the list of principles with the new ones provided by Article 4 of the Law of Ukraine (2013) "About Administrative Services".

Analyzed scientific positions Koliushko and Tymoshchuk (2006), Petovka (2014) and other researchers concerning the principles of organization and activity of public authorities allow to also formulate the 
principles of the provision of administrative services by the Ministry of Health of Ukraine in the investigated sphere, which should be based on the concept of proper governance. Rule of law, accountability, transparent nature of activity, adequacy and proportionality of responses, effectiveness, equality of rights of service providers are defined by the relevant principles. It is also necessary to consider the need to supplement the list of principles for the provision of administrative services in the field of health care, taking into account the interests of the recipient of the administrative service. The above list of principles for the provision of administrative services in the field of health care should be systematized according to the criterion of the limits of the basis formation (principles) of regulation: general principles of law, regulatory principles, principles of proper governance.

Perspective directions of further research are: 1) the special attention should be given to the introduction of the principle of legal certainty in the activities of public authorities in the provision of administrative services in the field of health care. The indicated principle directs such entities to ignore regulations of proper procedures by bylaw acts and active improvement of procedure nature; 2) the introduction of European experience, the experience of the United States, Great Britain in organizing the provision of administrative services in the healthcare field should be based on the principles of the proper procedure for the provision of administrative services, among which the principles of proper governance which necessitates the further development of e-government system. One of the directions of such development is the introduction of forms and means of information interaction between the Center for Administrative Services "Single Window" at the Ministry of Health of Ukraine and the Centers for the Provision of Administrative Services. Implementation of this proposal requires the development of certain normative and organizational propositions.

\section{Bibliographic References}

ALLALYEV, Ruslan. 2019. "Religious origins of the rule of law conception in the United States” In: Amazonia Investiga. Vol. 7, No. 14, pp. 212-217.

ASSOCIATION AGREEMENT BETWEEN THE EUROPEAN UNION AND UKRAINE. 2014. Available online. In: https://trade.ec.europa.eu/ doclib/docs/2016/november/tradoc_155103.pdf. Consultation date: 18/06/2020.

AVERYANOV, Vadym Bohdanovych. 2007. Administrative law of Ukraine. Yurydychna Dumka. Kyiv, Ukraine (In Ukrainian). 
Iryna M. Sopilko, Roza M. Vinetska, Nataliia B. Novytska y Oleksandr Lyubchik

AVTONOMOVA, Svetlana; KUTYRKINA, Lyudmila; FEDYUNIN, Dmitry; BEZPALOV, Valery; LOCHAN, Sergey. 2019. "GR in the university brand-communications system” In: Amazonia Investiga. Vol. 8, No. 19, pp. 173-178.

BAKHNOVSKA, Iryna Petrivna. 2011. Fundamental principles of law as an integrative element of the legal system of Ukraine. National Law Academy of Ukraine named after Yaroslav the Wise. Kharkiv, Ukraine.

DEMBITSKA, Susanna Leonidivna. 2010. Legal principles of activity on provision of administrative services to the population of Ukraine by local self-government bodies: thesis of the candidate of Law Sciences. State University of Internal Affairs. Lviv, Ukraine.

GORDADZE, Guram; KERIMOV, Vagif; GIRUTS, Maksym; POSHIBAEVA, Alexandra; KOSHELEV, Vladimir. 2018. "Genesis of the asphaltite of the Ivanovskoe field in the Orenburg region, Russia” In: Fuel. Vol. 216, pp. $835-842$.

GULIYEV, Ibrahim; KERIMOV, Vagif; MUSTAEV, Rustam; BONDAREV, Andrey. 2018. "The estimation of the generation potential of the low permeable shale strata of the Maikop Caucasian series" In: Socar Proceedings. No. 1, pp. 4-20.

GULIYEV, Ibrahim; KERIMOV, Vagif; OSIPOV, Alexander; MUSTAEV, Rustam. 2017. "Generation and accumulation of hydrocarbons at great depths under the earth's crust” In: Socar Proceedings. No. 1, pp. 4-16.

HOLOVATY, Serhiy. 2008. The rule of law: Idea, doctrine, principle: thesis of the candidate of Law Sciences. Institute of Legislation of the Verkhovna Rada of Ukraine. Kyiv, Ukraine.

KOLIUSHKO, Ihor; TYMOSHCHUK, Viktor. 2006. Effective public administration (directory for ministers). Centre for Political and Legal Reforms. Kyiv, Ukraine.

KRAVTSOVA, Tetyana Mykolayivna; SOLONNAR, Andriy Viktorovych. 2010. "Concepts and principles of the activity of public administration" In: Forum of Law. Vol. 4, pp. 522-525.

KUZMENKO, Oksana Volodymyrivna. 2004. Processal categories of administrative law. Lviv: JSC Lviv Book Factory “Atlas”. Kiev, Ukraine (In Ukrainian).

LAGODA, Oleksandr Serhiyovych. 2007. Administrative procedure: Theory and practice of application. Irpin: National University of State Tax Administration of Ukraine. Kiev, Ukraine. 
LAW OF UKRAINE. 2005. About authorization system in the field of economic activity, No. 2806-IV. Available online. In: https://cis-legislation.com/ document.fwx?rgn=10251. Consultation date: 20/06/2020.

LAW OF UKRAINE. 2013. On Administrative Services, No. 5203-VI. Available online. In: https://zakon.rada.gov.ua/laws/show/5203-17\#Text. Consultation date: 17/06/2020.

LAW OF UKRAINE. 2014. On the ratification of the Association Agreement between Ukraine, of the one part, and the European Union, the European Atomic Energy Community and their Member States, of the other part, No. 1678-VII. Available online. In: https://zakon.rada.gov.ua/laws/ show/1678-18\#Text. Consultation date: 21/06/2020.

LAW OF UKRAINE. 2015. About licensing of types of economic activity, No. 222-VIII. Available online. In: https://zakon.rada.gov.ua/laws/ show/222-19\#Text. Consultation date: 22/06/2020.

LEGEZA, Yevhen Oleksandrovych. 2011. Administrative services provided by public safety police: thesis of the candidate of Law Sciences. Dnipropetrovsk State University of Internal Affairs. Dnipropetrovsk, Ukraine.

MYKOLENKO, Oleksandr Ivanovych. 2010. Theory of administrative procedural law. Burkina. Kharkiv, Ukraine (In Ukrainian).

OBOLENSKY, Oleksiy Yuriyovych; GORBATYUK, Vasyl Ivanovych. 2013. "Administrative services in the field of public finance management". In: Public Administration: Theory and Practice. Vol. 1. Available online. In: http://academy.gov.ua/ej/ej17/PDF/18.pdf. Consultation date: 15/06/2020.

ORDER OF THE MINISTRY OF HEALTH OF UKRAINE. 2017. On approval of a unified form of an act drawn up on the basis of a planned (unscheduled) measure of state supervision (control) regarding compliance by the business entity with the requirements of legislation in the field of economic activity in medical practice subject to licensing, No. 1366. Available online. In: https://zakon.rada.gov.ua/laws/show/z144517\#Text. Consultation date: 15/06/2020.

PETOVKA, Vasyl Vasylovych. 2014. Providing administrative services in Ukraine: Theory and practice. Logos. Kyiv, Ukraine.

POGOSYAN, Vardhes. 2018. "Philosophies of social behavior research: metaanalytic review" In: Wisdom. Vol. 11, No. 2, pp. 85-92. 
Iryna M. Sopilko, Roza M. Vinetska, Nataliia B. Novytska y Oleksandr Lyubchik

POGOSYAN, Vardhes. 2019. "Change and variability of phenomena in complex social systems” In: Wisdom. Vol. 13, No. 2, pp. 95-103.

RESOLUTION OF THE CABINET OF MINISTERS OF UKRAINE. 2013. About approval of the Approximate regulations on the center of provision of administrative services, No. 118. Available online. In: https:// cis-legislation.com/document.fwx?rgn=58279. Consultation date: 19/06/2020.

SHEMSHUCHENKO, Yuriy Serhiyovych; AVERYANOV, Vadym Borysovych; ANDRIYKO, Olha Fedorivna; KRESINA, Iryna Andriivna; NAHREBELNYY, Volodymyr Petrovych. 2010. Democratic principles of public administration and administrative law. Yurydychna Dumka. Kyiv, Ukraine (In Ukrainian).

SOPILKO, Iryna; YULDASHEV, Serhiy; VINETSKA, Roza. 2019. "The principles of proper procedure formation for the provision of administrative services in the field of health care" In: International Journal of Advanced Biotechnology and Research. No. Special, Issue-1, pp. 446-455.

THE CONCEPT OF REFORMING PUBLIC ADMINISTRATION. 2020. Available online. In: http://www.pravo.org.ua/files/stat/Concept_ public_administration.pdf. Consultation date: 19/06/2020.

THE CONSTITUTION OF UKRAINE. 1996. Available online. In: http:// extwprlegs1.fao.org/docs/pdf/ukr127467E.pdf.

Consultation date: $14 / 06 / 2020$.

TURKOVA, Oksana Kostyantynivna. 2017. Legal nature of procedures for the provision of administrative services in Ukraine: thesis of the candidate of Law Sciences. National Law Academy of Ukraine named after Yaroslav the Wise. Kharkiv, Ukraine. 

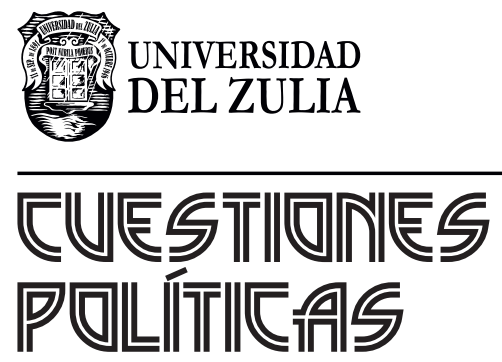

Vol.39 No 68

Esta revista fue editada en formato digital y publicada en enero de 2021, por el Fondo Editorial Serbiluz, Universidad del Zulia. Maracaibo-Venezuela 